\title{
EDITORIAL
}

\section{RELIGIÕES NO MUNDO}

\section{ANTIGO}

\section{CLAUDIA BELTRÃO DA ROSA ${ }^{1}$}

As grandes religiões atuais são fenômenos antigos. Isso é válido para o judaísmo, presente em várias cidades em torno do Mediterrâneo, e para o cristianismo em suas variedades. É também válido para o islamismo, uma religião oriunda do criticismo dos antigos politeísmos e de vertentes regionais judaicas e cristãs que, como o judaísmo e o cristianismo, também incorporou material clássico em sua cultura religiosa-intelectual. $E$ além do enquadramento estrito do Mediterrâneo, as grandes tradições religiosas atuais são também "antigas" o hinduísmo, o budismo, ou o confucionismo, e.g.

Estudar as religiões da antiguidade, contudo, é um desafio em vários sentidos e, talvez, um dos mais graves seja o fato de que, mesmo nas universidades, o estudo das sociedades antigas não é (ainda) uma prioridade no Brasil. Tal estudo nos leva a olhar para além das nossas fronteiras nacionais, culturais etc., ao passo que nos permite um acesso a um patrimônio cultural comum a vários povos atuais. É certo que esse patrimônio foi - e ainda é - objeto de disputas e conflitos identitários e, desde

\footnotetext{
${ }^{1}$ Profa. Associada de História Antiga da Universidade Federal do Estado do Rio de Janeiro - UNIRIO.
}

pelo menos o século XIX, o patrimônio histórico e as religiões foram vinculados à identidade dos Estados e das nações, que projetaram em seus mitos fundadores aquilo que definiram como sendo sua essência. Nessa busca de essências, monumentos e documentos foram investidos de funções muito importantes - às vezes, muito perigosas - para a vida em comum.

O estudo das sociedades da antiguidade nos fornece ferramentas e instrumentos cognitivos para compreender, dentre outras, afirmações concernentes a identidades - dos outros e de nós mesmos. E o estudo das religiões desempenha um papel destacado nessa compreensão. Ele nos permite opor aos discursos sectários as "armas" da história, da filologia, da arqueologia etc., desconstruindo os mitos modernos. Permite-nos abandonar os fantasmas das origens, dos passados imaginários, desmontando interpretações tendenciosas sobre o passado. Com ele, podemos contestar e superar equívocos modernos - intencionais ou não - sobre o "milagre grego", o "gênio romano" e coisas do tipo, bem como superar a dialética hegeliana e seus herdeiros que viam as religiões na história tendendo ao monoteísmo de tipo cristão. Os antigos gre- 
gos, romanos, judeus, cristãos etc. são tão distantes de nós quanto os aborígenes australianos atuais, e conhecê-los nos ajuda a desmontar os panos de fundo ideológicos de sua absoluta proximidade.

É certo que cada geração escreve sua própria história, e a história antiga de hoje é diferente das várias histórias antigas do passado. Paul Veyne, há quarenta anos, em sua Aula Inaugural no Collège de France, disse que a história só existe em relação às questões que nós lhe colocamos, e se perguntava quais seriam as questões que convinha fazer ao passado. ${ }^{2}$ Sigamos Paul Veyne neste ponto, dada sua frequência em bibliografias de cursos de História no Brasil e, mais ainda, pela atualidade de suas declarações: para ele, o ofício do historiador comporta dois aspectos, a erudição e a conceptualização. A pesquisa em história antiga exige que lancemos mão de vários recursos da erudição antes que possa ser formulado um novo questionamento, uma nova problemática. A história tem em Jano bifronte seu patrono: de um lado, o trabalho metódico com a documentação; de outro, o questionamento desses documentos. De um lado, a lide com a documentação; de outro, a problemática. Manejar as técnicas de pesquisa e os conceitos, e então a antiguidade se torna cada vez menos familiar e mais estranha, fazendo-nos rever preconceitos arraigados sobre a universalidade das ideias e dos comportamentos que, lamentavelmente, ainda são frequentes, permanecendo em uso e ativos, sendo propalados nos mass media, nas redes sociais, em campanhas políticas, em escolas, em universidades, no momento em que assistimos a uma exacerbação da religiosidade e de conflitos de base religiosa, que ressurgem como a fênix, com um vigor renovado.

Estudos sobre os discursos e as práticas religiosas da antiguidade vêm revelando aspectos antes insuspeitados das sociedades, e as religiões demonstraram ser um objeto de pesquisa de fundamental importância para a compreensão da experiência humana no tempo e no espaço. A pesquisa antiquista já ultrapassou uma ideia de

${ }^{2}$ VEYNE, P. L'inventaire des différences. Paris: Éditions du Seuil, 1976, publicado no Brasil pela Ed. Brasiliense, em 1983, sob o título O Inventário das Diferenças. "religião" compreendida como uma "essência trans-histórica", existindo como um fenômeno eterno e unitário. Ao contrário, as religiões mudam com o tempo e as circunstâncias, e também muda aquilo que as pessoas entendem como sendo "religião". As religiões, portanto, não são fixas, nem unitárias, e nem mesmo coerentes, e estão invariavelmente mudando, adaptando-se, recriando-se em realidades intersubjetivas. São fenômenos inerentemente sociais, criando experiências e significados compartilhados, práticas e imagens que são comunicadas e ensinadas. As pesquisas sobre as religiões antigas vêm se sucedendo em um ritmo acelerado nas últimas décadas graças, principalmente, ao diálogo interdisciplinar, o que permitiu a ampliação dos corpora documentais e, sobretudo, a reavaliação de dados e conclusões baseadas em documentos da tradição manuscrita e outros a partir de novas premissas, renovando a compreensão de temas já explorados pela historiografia sobre a antiguidade. As religiões antigas surgem sob novas luzes como elementos centrais na pesquisa e na compreensão, por exemplo, dos sistemas culturais, políticos, intelectuais e institucionais das sociedades do passado.

Ainda assim, as religiões da antiguidade formam um tema de estudo complexo per se, pois, seguindo-se uma das religiões atuais ou não, todos nós fomos formados - ou deformados - por dezesseis séculos de monoteísmo, e não é possível abandonar nosso mundo de compreensão e saltar simplesmente para outro. Desse modo, os contrassensos são vários e persistentes. Mas, não apenas no que tange à religião, como também em relação a outras manifestações culturais da antiguidade, é preciso ultrapassar o enquadramento do pensamento judaico-cristão. É certo que muitos estudos nos habituaram, nos últimos anos, à observação da alteridade. Mas a reiteração da necessidade da observação das categorias discursivas, religiosas e ideológicas das sociedades antigas merece ser feita, posto que o próprio desenvolvimento dos estudos sobre as práticas e os discursos religiosos da antiguidade ainda se dá pleno de ideias fundadas em "premissas monoteístas" que agem como pano de fundo de boa parte da pesquisa sobre a religião, analisando-a a partir de categorias religiosas judaico-cristãs. 
Este dossiê congrega artigos de estudiosos brasileiros e estrangeiros que lidam com práticas e crenças religiosas da antiguidade, observando aspectos religiosos cruciais para a compreensão das sociedades analisadas, bem como lidam com a transformação de práticas e crenças religiosas que levaram à formação de novas fronteiras e novos conhecimentos para os grupos humanos. As religiões antigas são aqui entendidas como um spectrum de ações, crenças, experiências, conhecimentos e comunicações com seres e agentes super-humanos, incluindo, mas não se limitando a "deuses", "demônios", "anjos", "heróis" e outras personagens transcendentes. A ritualização e as elaboradas formas de representação e apresentação dessas ações e experiências e desses seres e agentes são um tema de pesquisa atual para diversos ramos especializados em regiões, épocas, tradições e corpora documentais particulares.

A institucionalização da religião, assim como os papéis religiosos; a construção da religião como conhecimento; os rituais como produtos de contextos históricos e sujeitos à mudança, como testemunhos de tensões sincrônicas e/ou diacrônicas; os espaços das experiências religiosas, compartilhados por indivíduos ou grupos em santuários públicos ou privados, ou o espaço móvel dos festivais e procissões; o espaço religioso virtual da comunicação literária e os discursos intelectuais sobre a religião; os diferentes modos de apropriação das religiões, de comunicação com o "outro" invisível, representado ou epifânico; rituais e performances e sua relação com o corpo, em que movimentos e gestos são elementos fundamentais na percepção e estruturação de mundos religiosos; as imagens de deuses e de rituais e a criação de sentimentos e conhecimentos compartilhados, criando regimes de visualidade, são temas caros aos estudos sobre as religiões antigas, permitindo a análise de culturas religiosas criadas pelas interações interpessoais e intergrupais, pela imitação, apropriação de gestos, imagens e conhecimentos que criam comunidades fundamentadas em memórias compartilhadas, sempre sujeitas a mudanças. A intenção de reunir "religiões" diversas, especialistas, disciplinas e enfoques variados visa ao cruzamento ou à redefinição de fronteiras disciplinares e convida ao engajamento com discussões contemporâneas nos campos da pesquisa e do ensino das religiões, da história antiga, e das ciências humanas e sociais em geral. 